\title{
Enhancing Teachers' Professional Curriculum Practice in Sex Education in a Grade Ten Life Orientation Class
}

\author{
Emma Tshelane \\ Free State Department of Basic education, South Africa \\ tshelaneen@webmail.co.za \\ Molaodi Tshelane \\ University of Free State, School of Social Sciences and \\ Language Education, South Africa \\ TshelaneMD@ufs.ac.za
}

\section{Doi:10.5901/jesr.2014.v4n6p287}

\begin{abstract}
This article documents the research processes followed by a coordinating team for the subject of life orientation in a school. The aim is to enhance life orientation teachers' professional curriculum practice in pedagogy. The focus is on sex education and cultural influences on the behaviour of four hundred and forty school community members in Motheo district. Critical emancipatory research was used as the theoretical framework to guide the research process. Participatory action research was used as an approach for data generation. Critical discourse analysis was applied for the interpretation of, and to arrive at the following findings: the impact of gender roles, age and experience of teachers has a bearing on teaching sex education; cultural beliefs are a barrier to teaching sex education; and the legacy of colonialism and apartheid education has had a profound impact on education in South Africa.
\end{abstract}

Keywords: Enhance, Sex education, Professional Life Orientation

\section{Introduction and Background}

In South Africa, the Department of Basic Education's curriculum theme 'relating to decision making regarding sexuality' is an issue which fits into the broader topics of the Life Orientation subject in grade 10 (DBE, 2011:10). According to Francis, (2012:598) Life Orientation was introduced as a subject in South African schools in the late 1990s, due to educational reform aiming at the eradication of apartheid education. Despite the inclusion of topics such as 'Sexuality' in the South African school curriculum, Francis and many scholars are troubled by the conspicuous silence on issues of sex education in life orientation classes (Beyers, 2012:369; Beyers, Nkoane, 2012:666;Francis, 2012:598; Beyers \& Hay, 2011:99; Khau \& Pithouse, 2008:40; Beyers \& Hay, 2007:390). Furthermore, this challenge does not just rest with South Africa.

In Russia there is a lack of trained teachers in the area of sex education and HIV prevention (Avina \& O'Connell, 2006:2). Russian schools do not provide health or sex education as part of the school curriculum; however, when such knowledge is imparted it takes place in the context of the science subject (Jaworsky, Larkin, Sriranganathan, Clout, Janssen, Campbell, Flicker, Standnicki, Erlich \& Flynn, 2013: 228).

In Nigeria there is no curriculum to deal with gender, cultural sensitivity and life skills, and HIV/AIDS education. Therefore, teachers are ill prepared to deal with sex education (Alabi, Bahah \& Alabi, 2014:406). Little is done regarding the protection of child rights and of enhancing the opportunity for children to receive education in a safe and free environment which ensures gender and cultural sensitivity and includes life skills and HIVIAIDS education (Alabi, Bahah \& Alabi, 2014:406).

A recent study by Kasonde (2013: 3) has found that Botswana school curricula do not cover topics on abortion and communication and negotiation skills to reduce the risks of HIV, of other sexually transmitted diseases and of pregnancy. The major barriers to sex education are cultural and a lack of training, particularly teacher training in sex education.

In South Africa around 2001, the widely reported case of the rape of 'baby Tshepang' in the small community of Lousvale, located in the Northern Cape of the country caused shock waves amongst children's rights activists and the 
world in general (Dutton, 2013:243). Recently, the South African audio-visual media and newspapers have been reporting widely on the alarming figures released by the South African provincial departments of basic education indicating that school girl pregnancies have doubled in the past few years, despite a decade of spending on sex education and awareness (IRIN, 6 March 2007).

Notably, sexual behaviour among teenagers is a cause of concern. Sexting has been an issue in South African schools (Lamb, Graling, \& Lustig, 2011:366). Sexting is sending sexually explicit messages via cell phone or instant messenger (family internet.com). As technology has advanced and cell phones have the adeptness to record and send photographs and videos, the exercise of sending suggestive and explicit images has increased, especially among youngsters with incidents of rape and other sexual assaults increasing rapidly. According to Matlala (2011:4), the estimated pregnancy and HIVIAIDS infection rates are as follows: 250000 school children, 40000 teachers, 20\% of the labour work force and its rising to 25\% in 2005 (Kivela, Ketting, \& Baltussen, 2013:17). In Kimberley, a six-week-old baby was raped by his uncle (Halata \& Beangstrom, 2 December 2013). It is for the above reasons that we decided to undertake this study and it is thus appropriate to present the concrete statement of the problem.

\section{Problem Statement}

The main purpose of this study is to explore the reasons for the silence of teachers on teaching sex education in class. We were troubled by this silence, while sex related crimes are increasing at an alarming rate. We intend to find out why life orientation teachers are so silent whilst women and children, particularly girls, are being brutally murdered in sex related matters. Thus, this study intends to answer only one question: How does one enhance the professional curriculum practice of grade 10 life orientation teachers in teaching sex education in a school? Life orientation teachers do not know how to handle the sexual nature of the content in their curriculum practice. Some teachers are not conversant with the content, thus find it difficult to handle sensitive issues in life orientation, particularly, sex education. It is not known why they find it difficult to be able to impart this crucial knowledge when they discharge their professional curriculum practice in schools.

\section{Theoretical Framework}

This article is rooted in critical theory and more specifically, in critical emancipatory research (CER). CER advocates closeness between the researcher and researched (Cohen, Manion \& Morrison, 2011:37). The researched are not treated as if they are mere impersonal objects in a natural science laboratory; with CER they are recognised and valued, and thus treated with respect as fellow humans by the researcher (Mahlomaholo \& Nkoane, 2002:74; Mahlomaholo, 2009:225). CER advocates peace, hope, equality, team spirit and social justice; thus, CER is changing people's hearts and minds, liberating and meeting the needs of real life situations. In critical theory, every human being is important, with the assumption being that we are shaped by the society from which we come (Foulger, 2010:135). In particular, it is important to emphasise the use of democratic approaches and equality principles in matters of social interest, so as to bridge the gap between theory and practice. For instance, MacCabe and Holmes (2009:1519) argue that critical research involves the co-creation of the research agenda by the researcher and the researched participants. Therefore, this justifies our adoption of this paradigm; the main problem being teachers not able to teach sex education as required by the curriculum and the assessment policy statement of the department of basic education (CAPS) (DBE, 2011:4).

\section{Research Methodology and Design}

This enquiry is essentially qualitative in a participatory action research (PAR) approach. We decided to use participatory action research because its fundamental principles are similar to the critical emancipatory research theory. It is a more human oriented and above all, has been used by most teachers of life orientation in the cluster meeting of Motheo district spontaneously and not for research purposes. It can be regarded as an indigenously grounded, since in African culture people come together to assist one another during difficult times. Furthermore, PAR was preferred by the team of teachers working towards improving our teaching skills. PAR was thus accepted by all participants and was used in order to operationalise the study. It advocates empowerment and emancipation which are central to all participants and applicable to CER as the paradigm through which this entire study progresses. PAR is more than a methodology; it is an approach and because it fits well in CER as the lens of choice, its use was unanimously agreed upon. Only one question was formulated by the team which sought answers to: How does one enhance the professional curriculum practice of 
grade 10 life orientation teachers for teaching sex education in a school? The study involved collective, community-based research, since all the participants benefited on the basis of shared responsibility. In this way, all participants were engaged in critical dialogue, in attempting to respond to the question at hand. There was a collective agreement on problem identification; voluntarism and collective reflection; mutual benefit; and alliance reliance by participants from in the school community. They seemingly built up an eagerness to participate in this research project and their engagement and involvement in it was a positive sign which stimulated participation.

This was driven by a social vision shared by the researchers (ourselves) and the co-researchers (parents, teachers and community members) and clearly articulated by the team leaders operating from a collective decision (Gunter \& Fitzgerald, 2008:270). According to Galletta and Jones (2010:345), the crux of the above approach is grounded in collective reflection and action. People work together in three learning cycles, namely education and analysis; investigation; and action. This approach foregrounds the practical aspect of this research methodology (Dufour, 2002:23). The team members came together in a plenary meeting from different subjects: maths teachers, a language learner representative council, the school governing body and members of the school management team. We learnt from the presentations of others. They then critically interrogated the failures of Life Orientation and also extended the problems to the community and families. The team rallied and marshalled support from everyone in the school under a theme: 'Knowledge is power, but is more powerful if you share it', which, based on regular educational projects, enabled collective reflection and received feedback.

\subsection{Data generation procedures}

The Free Attitude Interview (FAl) technique advocated by Ineke Meulenberg-Buskens (2011:1) was used as the instrument for data generation because it has elements of respect for persons, with the question used only as a means to initiate a conversation. This then was followed up by a reflective summary which persuaded and encouraged team members to think prudently and carefully about their arguments (Mahlomaholo, 2009:228, 2011:45, 2012:4). The term Free Attitude Interview can be traced back to Vrolij and Timmerman (Meulenberg-Buskens, 2011:1). MeulenbergBuskens argues that FAI is non-directive in nature and opens a space for participants to intervene and thus make it possible for the researcher and the researched to assess and negotiate issues of reliability and validity emphasised in positivist and phenomenologist paradigms (Buskens, 2011:2). FAl enabled us to employ reflexivity as a means of controlling the effects of researcher bias and its influence on the research process.

Based on the above information we wrote a letter to the school management team (SMT) on the advice of the principal, to request permission to conduct research. We were granted permission and in the first meeting we presented our case in one of the morning briefing sessions. We realised that the majority of the participants (Our colleagues) were concerned about sex related cases escalating in education. The meeting resolved to form a team which would consist of learners, non-teaching staff, teachers, members of the SGB and stakeholders from the community. From these stakeholders a coordinating team of five members was established.

\subsection{Instrumentation}

The coordinating team agreed to meet every Wednesday after school and we used different tools to keep current information for sharing and conversations. These tools involved cell phones and emails, where we used short message services (SMS), whatsApp, and Facebook. What was more encouraging to observe was the commitment of all participants as we followed a tried and tested programme. We had regular meetings every Wednesday after school, starting with a discussion of the problem, then engaging in a SWOT analysis and team-building exercises, and gathering data through dialoguing in different focus groups. Anyone could be approached to help when we needed assistance. We also developed a vision and set priorities to achieve our goal (Kemmis, 2008:345). One participant who was previously involved in PAR emphasised that everyone should understand the double role of the researcher and the researched, and that all school community members mentioned above should not be forced to participate and that this should be stressed in all the meetings. We used note books to record conversations in our meetings

\subsection{Intervention}

PAR was applied, since it seemed to be the appropriate method for the type of intervention required in this study due to its elements of practical intervention techniques. These techniques focus on emancipation, which is in line with critical 
emancipatory theory/critical leadership theory advocating the emancipation of both the leader and the followers from oppression due to established power structures (Leedy \& Ormond, 2010:43; Creswell, 2009:35; Yuen, Law \& Wong. 2003:168). Intervention in the context of this study refers to the actual actions we took after identifying the problem. Thus, after identifying the undesirable situation in the educational field, we committed ourselves to investigate this situation and gain a deeper understanding of why Life Orientation teachers in grade 10 are not confident enough to present the sex education content promulgated by the CAPS document (Cossa, \& Cronje, 2004:243, Rebore, 2011:141). However, this task cannot be carried out by an individual. In this regard, We reflected on the arguments of Steve Biko when he addressed the South African Students Organisation, persuading them to help rebuild homes which were destroyed by the then apartheid government in Inanda near Durban in 1970: "We need to work side by side with the people, and in this way we can get to know them well and also discuss our political ideas with them so that they can help us too" (DworskiRiggs \& Langhout: 2010:218; Kumar, 2005:8).

\subsection{Profiling of participants}

Participants in the project were made up of eighty grade 10 life orientation learners; fifty-eight parents of the grade 10 life orientation learners; fifty-three staff members inclusive of the researchers; twelve members of the school governing body; a community development officer; an 'adopt a cop' (police officer); a community member; and a pastor from the local church in the community. All in all, members who participated in the project totalled two-hundred-and-six.

\subsection{Data analysis}

The collected data were analysed through a means that would enable us to have a deeper understanding by interpreting the collected data and reflecting on our interpretation. To analyse the collected data we used critical discourse analysis (CDA) advocated by van Dijk. We adopted critical discourse analysis (CDA) as the means of interpretation. We chose $\mathrm{CDA}$, because it acknowledges the need to examine, in practical terms, how one goes about doing a critical analysis of text and talk (van Dijk, 2011:89). Furthermore, we opted for critical discourse, because CDA wants to know that structures, strategies or other properties of text, talk, verbal interaction or communicative events play a role in the modes of the reproduction of power relations, enactment, representation, legitimation, denial, mitigation or the concealment of dominance among others (van Dijk, 2011:93; Govender \& Muthukrishna, 2012:29). Furthermore, CDA can be used as a means for the explanation, description and interpretation of the generated data (van Dijk, 2003:352; Vos et al., 2005:430). Critical discourse analysis is a technique used primarily in studies to expose how social power is abused, as well as how dominance and inequalities are enacted, reproduced and resisted by text and talk in social and political contexts as indicated in the paragraph above (Vos et al., 2005:431). CDA is a type of discourse that requires the connection between the language used and the social context in which it occurs as an issue of gender, ethnicity, cultural difference, ideology and identity (Shopen, 2013:221). Through CDA we explored how the connections used in language and in the social context are constructed and inflicted in text (Paltridge, 2006:10). Thus, CDA was used to show what structures, strategies or other properties of text, talk, verbal interaction or communicative events play a role in these modes of the reproduction of domination and power relation inequality are revealed (van Dijk, 2009:250).

This information was generated in the form of minutes of meetings and virtual discussions on social network, as well as e-mails and SMSs. We opted to use critical discourse analysis since it focuses on an understanding of what structures, strategies or other properties of text, talk, verbal interaction or communicative events play a role in these approaches of knowledge production (van Dijk, 2003:250; van Dijk, 2009:230). We also based our understanding on a sound comprehension of the computer learning models from the workshops conducted by the Vodacom expert.

The Wednesday meeting workshops and focus groups were recorded as minutes. After every meeting, as the Secretariat, we had to record the corrected minutes with the chairperson of the coordinating team and send out copies to all members of the coordinating team for reflection (Kemmis \& Mc Taggart, 2000:12). All minutes were distributed at the next meeting and the coordinating team read the minutes and validated them so as to confirm whether we had a common understanding of the proceedings. The advantage of reviewing the minutes was that all members of the coordination team became involved in correcting any misunderstanding of what transpired in the meetings.

\section{Discussion of Findings}

An analysis of the data and discussion based on the constructs derived from the literature were used to arrive at the 
findings in the journey towards improving the professional curriculum practice of grade 10 life orientation teachers centred on the following premises. Teaching sex education in a school is based on the view that teachers draw upon particular understandings of culture for progressions of other occurrences, namely, silence, violence and poverty (DePalma \& Fancis, 2014:547). The following findings were arrived at: the teaching of sex education in South African schools has over looked the impact of gender roles, the age and the experience of teachers. Cultural beliefs serve as a barrier to sex education. Finally, the legacy of colonialism and apartheid education has had a profound impact on education in South Africa. These findings will be discussed below.

\subsection{The impact of gender roles, age and experience of teachers has a bearing on teaching sex education.}

According to the Life Orientation Curriculum and Assessment Policy Statement (CAPS) (DBE, 2011:10), teachers must address a curriculum topic entitled 'Development of the Self in Society'. This topic must be addressed in term two, week 1 to 3. Three themes must be handled and one of the themes is Sexuality: attitudes, values and behaviour. The subthemes based on sex education include the portrayal of sexuality in the media, as well as cultural and social perspectives on sexuality. Research has attested that this topic has been neglected in classroom curriculum practice, due not just to a lack of pedagogical content knowledge, but to deep seated convictions and the belief systems of some educators (DelPalm \& Francis, 2014: 549; Moletsane, 2011:198; Khau \& Pithouse, 2008:40). This view was confirmed by Miss Dikeledi, a young teacher recently employed to teach grade 10 Life Orientation who was one of the participants in a focus group session we had at the school. Her comments are recorded in the extract below:
Miss Dikeledi: The learning facilitator for Life Orientation, Mr Buang, is serious with this thing ... Just imagine Me teaching grade 10 learners about sex education; you know those learners already know everything. Besides, it will make those boys undermine me even more; I do not have time to play. I could possibly be charged with misconduct.

The extract above shows that the teacher was inconsistent in her approach to the Life Orientation curriculum policy provisions, which require her to teach the prescribed content which was clarified by the learning facilitator to concretise the curriculum expectations of encouraging critical thinking and active learning (Mahlomaholo, 2010:10; Niemi, 2002:763-764) by the learners. These inconsistencies suggest that the teacher was in direct contravention of the policy provisions, and being consciously aware that she would be contravening the law.

However, if we look deeper into the issues raised by the teacher it seems that the teacher was not prepared to teach grade 10 learners, given her young age. She had just entered the teaching profession, so it could be that she feels too young to be engaging learners in topics regarding sexuality. The second aspect which can be seen from the teacher's argument is the gender problem. Clearly, the teacher is troubled only by 'Boys'; although the class comprises a mixed gender, her concerns were centred only on boys. From the statement of the teacher, elements of inexperience are conspicuous; since the teacher even considers her being charged with misconduct, this suggests that she obviously feels over whelmed by the boys in her class who will make provocative advances and statements given her youth (LadsonBillings, 2005:115).

Based on the discussions above, it can be concluded that the impact of gender roles, and the age and experience of teachers has a bearing on teaching sex education. The teacher feels oppressed by the learning facilitator and the requirements of the CAPS document. This is so since CDA can be used in studies of relations between discourse, power, dominance, social inequality and the position of the discourse analyst in relation to spoken words and text (van Dijk, 2003:249). CDA requires accounting for the intricate relationships between text talk, social cognition, power, society and culture which we followed in this study.

\subsection{Cultural beliefs are a barrier to teaching sex education}

Francis (2014:2) points out that teachers are reluctant to address issues of gender and sexuality. This is presumably rooted in what teachers understand as cultural taboos against certain behaviours and practices that include discussions between teachers and children about sex and sexuality. The point that Francis makes is partially validated by the argument between Mr Ma-Vic and Mrs Duti. Mr Ma-Vic and Mrs Duti both in their early fifties, hold different views regarding the teaching of sex education. In one of our regular Wednesday meetings the following is what these teachers wrote: 


\begin{abstract}
Mr Ma-Vic : I cannot understand what is so difficult to talk about sex education. These learners know everything about sex and some of them have children, and you should not undermine them. In my Life Science classes we talk about everything; you might have seen that there are different pictures of different sex organs, hanging on the wall. We call every private part just that and in fact, my learners enjoy the lessons on reproduction more than anything. Honestly, I cannot understand it when other teachers say that they find it difficult to talk about what these learners know.

Mrs Duti: You should understand that we are from different cultural backgrounds and we have been socialised differently. We do not talk about sexuality as open as you do; besides you are 'a Bloemfontein child'; you always use vulgar words freely which is not the case with us. Today education is just something that some of us cannot understand really what is happening with this liberal education. Look now, we cannot do anything with our learners; they do funny things, in the name of Gays and Lesbians. What is that? They do not respect us anymore. In my home town our children are well mannered.
\end{abstract}

The conversation above shows that there are still different views regarding the teaching of sex education in Life Orientation. It seems that not all teachers are in favour of the pedagogical content taught in Life Orientation. This argument is confirmed in the literature on the silence with regard to the teaching of sex education. It seems that teachers use culture as the reasons for keeping silent on sex education. This practice is also hidden by the fact that Life Orientation is not examinable, externally which may have an impact on the achievement of the lesson objectives in grade 10.

Looking deeper into the arguments of Mr Ma-Vic, it seems that the teacher is comfortable with issues of sex education. These views of Mr Ma-Vic also raise an important policy matter which would require further research pertaining to where to locate the pedagogical content that deals with sex education. For instance, in Russia sex education is presented in the subject of Biology (see introduction above).

Furthermore, it is clear that Mrs Duti is not comfortable with teaching sex education which can be the answer to the question why teachers are not teaching sex education as required by the life orientation curriculum. This validates the point raised by Francis that culture is another aspect which serves as a barrier to the teaching of sex education to learners. On the other hand, Mr Ma-Vic who is a Life Science teacher is able to teach issues of sexuality with confidence. This also confirms the literature that in Russia sex education is dealt with only in a biology lesson (Jeenah \& Pouris, 2008: 23). Thus it can be concluded that for teachers to be able to teach sex education, the advocacy of and a conscious decision regarding cultural issues must first be addressed.

\title{
5.3 The legacy of colonialism and apartheid education has had a profound impact on education in South Africa
}

The research findings of DePalma and Francis (2014: 557) indicates that despite the progress made in South Africa through post-apartheid reconciliation which has justified admiration throughout the world, there is still a tendency to cast Africans as a unified cultural group which characterises 'African culture' as less progressive and associated with certain inherent cultural deficits such as laziness and excessive sexuality. The authors further propose a need for teachers' education to actively challenge lingering colonial and apartheid constructions of race and culture. This is evident in the conversations below:

Mme Lesego: We had our own way of imparting sex education to our children (learners); now all of that has been destroyed by acculturation today and our humanity is fading away. The colonial masters have messed up our good practices, such as 'Ukuhlonipha' (to respect), which is no more, and there is nothing we can do now.

The above statement mention by Mme Lesego, a parent and non-teaching staff member indicates that respect has been lost due to the actions of the colonisers who regarded African culture as inferior. This implies that the parent in the above comment has observed that African education has been disregarded in favour of colonial education. The word 'Ukuhlonipha' was regarded as the best education a person can have, since respect can only happen when a person starts with him/herself.

This sentiment shows that the parent has identified social issues to challenge the education of South Africa, which has neglected the rich indigenous knowledge system, since much of the great African philosophical teachings have not been infused into formal education in the country. It seems that these sentiments have been ignored at the expense of the African child. The silence in teaching sex education reflected in the phrase "there is nothing we can do" shows an inability to take responsibility. It could also be interpreted as indicative of the impact of power on learning and teaching practices (Smith, Yosso \& Solorzano, 2006:234). In this instance, it could mean that abuse of power or excessive power can lead to distortions and misinterpretations of policy imperatives (Laisodou, 2008:486; Sheyholislami, 2009:3; Van Dijk, 
2008:88). In this case, the department which has the power to determine policy and monitor its implementation through such workshops could be viewed as also contributing to deviant practices.

The department is projected in the light of a 'dictator' who restricts his 'subjects' and 'subordinates'. In the same vein, it could be that the facilitator 'uses the power of the department' as its representative to subjugate the voices of teachers about appropriate teaching methods (Stein \& Mankowski, 2004:21; Swantz, 2008:33-34). It is therefore critical that structures such as the Education District Support Teams, made up of teacher representatives and government officials (DBE, 2011b:3-5) give expression to and create space for freedom of expression by local teachers and equity for social transformation. Such structures would temper the power of the department as all participants therein are required to debate and defend their arguments freely, without appeal to authority. What counts most during such conversations is the power of the argument, not the status of the participant.

\section{Conclusion}

The process of conducting participatory action research has brought in practices which view all human beings as important. The voices of participants can be heard irrespective of class and status. The most important undertaking is to indicate that ordinary people can help address teaching and learning problems and that dependence on just expert knowledge can be costly. Life orientation teachers have to be mindful of the fact that when faced with challenges, one can always learn from others, particularly if they are also committed to the problem. They can also draw up lessons from what other people do and think about sex education in order to improve their own practices. Although the research report focused only on the first circle of the participatory action research project, many lessons can be drawn up to guide the teacher with regard to sex education through reflection and as such, breaking the silence reported by researchers.

The transference of the absence of a structure to mitigate and mediate these problems amongst teachers, between teachers and learners and all other stakeholders makes the situation worse. Cultural constraints have denied teachers the opportunity (Nkoane, 2011:119) of conducting their situational analysis of sex education in Life Orientation content knowledge and pedagogy; of developing their teaching guides and lesson plans together; of sharing experiences and supporting one another; of reflecting and giving one another feedback; and of assessing and discussing learners' performance (Idowu, 2011:134; Salleh, 2004:5-8).

\section{References}

Alabi, Bahah \& Alabi, (2014). The girl-child: a sociological view on the problems of girl-child education in Nigeria. European Scientific Journal. vol.10, No.2

Avina, \& O'Connel, (2006). Russian Science Teachers' Knowledge of HIVIAIDS: Landon:Sage Publishing

Beyers, C. \& Hay, J.(2011).Supporting HIV-Positive Learners in Inclusive Classes in South Africa: Is It the Responsibility of Teachers? Kamla-Raj J Soc Sci, 26(2): 99-104.

Beyers, C. \& Nkoane, M.M.(2012).Troubling Discourse: The Social Justice Approach Towards Combating Hiv And Aids Stigmatisation Among Adolescents. Journal of Psychology in Africa. 22(4), 665-668.

Beyers, C. (2012). Picture that: supporting sexuality educators in narrowing the knowledge/practice gap. South African Journal of Education. Volume, 32(4) November.

Beyers,C. \& Hay,J.( 2007).Can inclusive education in South (ern) Africa survive the HIV and AIDS pandemic? International Journal of Inclusive Education. 2007. Vol. 11, No. 4, 387-399.

Creswell, J.W.( 2009).Research design: Qualitative, quantitative and mixed methods approaches.3rd Edition. London: SAGE.

DePalma, R. \& Francis, D. (2014). Silence, nostalgia, violence, and poverty...: What does 'culture' mean for South African sexuality educators? Culture, health \& sexuality: an international journal for research, intervention and care. Vol.16,No.5: 547-561.

Dutton, J. (2013). Layers of Violence: A Gender Perspective on Media Reporting on Infant Rape in South Africa, in Marcia Texler Segal, Vasilikie Demos (ed.) Gendered Perspectives on Conflict and Violence (Advances in Gender Research, Volume 18), Emerald Group Publishing Limited, .243-272.

Francis, D. A. (2012). Teacher positioning on the teaching of sexual diversity in South African schools. Culture, Health \& Sexuality.Vol. 14, No. 6, 597-611.

Govender, D. \& Muthukrishna, N. (2012). Towards Sustainable Learning Environments: Deconstructing discourses of Social Justice in the English home language classroom. (17): 21-24.

Halata, C. \& Beangstrom, P.( 2013). Raped baby heading home soon. December 22013 at 10:08am

Hongwana, V. A. (2009). Deconstructing Higher Education Transformation as Trauma through Narratives. Potchefstroom: Science Africa.

IRIN.(2007). Breaking News \& Weather-All-In-One HeadlineAlleyRelating to breaking news on-line news application. new p (6 march 2014) 
Jaworsky,D. Larkin,J. Sriranganathan, G. Clout, J. Janssen, J. Campbell, L. Flicker, S. Standnicki, D. Erlich, L. \& Flynn, S. (2013). Evaluating Youth Sexual Health Peer Education Programs: Challenges and Suggestions for Effective Evaluation Practices. Vol 1, no.12013.

Jeenah, M. \& Pouris, A. (2008). South African research in the context of Africa and globally. South African Journal of Science. Online at www.sajs.co.za [accessed on 12 February 2014]

Kasonde,0. (2013). Perception of teachers to sexuality education in secondary schools in Gaborone, Botswana. Master Theses: Cape Town: Stellenbosch University.

Kekale, J. \& Pirttila, J. (2006). International Journal of leadership in Education: Theory and Practice: Participatory action research as a method of developing leadership and quality. 9:3, 251-268.

Kemmis, S. \& Mc Taggart, R. (2000). Participatory Action Research. In Denzin, N.K. \& Lincoln, S.Y. (eds).http://www.sagepub.com lupm-data/21157-hapter10.pdf [ accessed on 07 March 2014]

Kemmis, S. (2008). Praxis and Practice Architectures in Mathematics Education. School of Education. Charles :Strut University.

Khau,M \& Pithouse, K. (2008).Africa Studying Ourselves as Scholar-Teachers in the Age of HIV and AIDS in Southern. Human Architecture: Journal of the Sociology of Self-knowledge spring.. (6), 2, 39-48.

Kivela, J. Ketting, E. \& Baltussen, R.( 2013). Cost analysis of school-based sexuality education, programs in six countries. Cost Effectiveness and Resource Allocation 11:17. http://www.resource-allocation.com/content/11/1/17 Accessed: 15/03/2014. Race ethnicity and education: The evolving role of critical race theory in education. University of Wisconsin-Madison, New York. Race Ethnicity and Education 8 (1): 115- 119.

Lamb, S., Graling, K. Lustig, K. (2011). Stereotypes in Four Current AOUM Sexuality Education Curricula: Good Girls, Good Boys, and the New Gender Equality. American Journal of Sexuality Education, 6:360-380.

Leedy, P.D. \& Ormrod, J. E. (2010) Pratical Research. Planning and Design. Boston. Pearson Educational International.

Mahlomaholo, M.G. (2012). Academic Network and Sustainability Environments. Networks in the Global World Conference. Global networks Conference at St Petersburg State University, Russia, June 22-24.

Mahlomaholo, M.G. (2010). Towards sustainable empowering learning environments: Unmasking apartheid legacies through scholarship of engagements. South Africa Journal of Higher Education 24(2): 287-301.

Mahlomaholo, S. \& Netshandama, V. (2011). Post-apartheid organic intellectuals and knowledge creation. In Bastov, N. \& Nenko, O. Understanding Knowledge creation.Intellectuals in academia, the public spheres and the Arts: Amsterdam.

Mahlomaholo, S. \& Nkoane, M. (2002). Quality in qualitative research: The case for critical emancipatory research. Reflection on assessment of quality. Journal of Education as change. Vol.6. (1): 69-84.

Mahlomaholo, S. (2009). Re-membering the organic intellectual in the mirror: Inaugural lecture held 21 August 2009. Potchefstroom: North-West University.

Mahlomaholo, S.M.G., Francis, D. \& Nkoane, M. M. (2010). Creating sustainable empowering learning environments through scholarship of engagement. South African Journal of Higher Education 24 (3): 281-286.

Matlala,M.Y. (2011). The role of social factors in influencing the moral development of black adolescents a PhD thesis: Bloemfontein: University of the Free State

McCabe, J. M. \& Holmes, D. (2009). Reflexivity, critical qualitative research and emancipation: a Foucauldian perspective. London: Blackwell Publishing Ltd.

Meulenberg-Buskens, I. (2011). Free attitude interview technique. London: Unpublished notes.

Moahi, K. (2007). Library and Information Science Research in Botswana: An Analysis of Trends and Patterns. World library and Information Congress: 73rd IFLA General Conference and Council, 19-23 August 2007, Durban, South Africa. Available at:http://www.ifla.org/iv/ifla73/index.html [accessed 20 February 2014]

Mutula, M.S. 920090. Challenges of Postgraduate research: Global context, African perspective. Delivered at the University of Zululand, $10^{\text {th }}$ DLIS Annual Conference. 9-10 September.

Nkoane, M.M. 2012. Critical emancipatory research for social justice and democratic citizenship. Journal of Perspectives in Education. 30(4) 98-104.

Pathera, S. (2007). Demystifying inclusion: implications for sustainable inclusive practice. International Journal of Inclusive Education.Vol. 11, 5-6. 627-643.

Republic of South Africa. (2011). Basic Department of education National Curriculum Statement: Curriculum and Assessment Policy Statement. Pretoria: Government print

Republic of South Africa. (2011). Basic Department of education. (CAPS).Life Orientation Further Education and training Phase. Pretoria: Government print.

Smith, W. A., Yosso. T.J. \& Solorzano, D.G.( 2006). Challenging Racial Battle fatigue on Historically White Campuses: a critical Race Examination of race-related Stress. Anker Publishing.

Van Dijik, T.A. (2009). Critical discourse studies. A socio-cognitive approach. In Wodak, R. \& Meyer, M. (eds). Methods of critical discourse analysis. London: Sage.

Van Dijk, T. A. (2003). Principles of Critical Discourse Analysis. Discourse \& Society.4(2): 249-283. 